\title{
Active phytochemical and antibacterial potentiality of in-vitro regenerated plantlets of Canscora decurrens (Dalzell)
}

\author{
A. Mungole ${ }^{1}$, S. Day, R. Kamble, H. Kanfade, A. Chaturvedi and P. Zanwar \\ Department of Botany, RTM Nagpur University, Nagpur-440 033, India \\ ${ }^{1}$ SFS Centre for Biotechnology, St. Francis De Sales College, Seminary Hills, Nagpur-440 006, India. \\ aru.mungole@gmail.com
}

\begin{abstract}
The present paper deals with in vitro produced phytochemicals of Canscora decurrens (Dalzell) such as alkaloids, flavanoids, phenols, steroids, anthracene glycosides and triterpenoids etc for their antibacterial activities against human pathogenic strains viz. Staphylococcus aureus, Bacillus subtilis, Rhodococci sp., Escherichia coli, Proteus vulgaris, Pseudomonas $s p$, Salmonella sp. and Bacillus stearothermophilus. The investigation suggests that the plant may be used in therapeutic treatments of gastrointestinal disorders, diarrhoea and skin diseases.
\end{abstract}

Keywords: Phytochemical, regeneration, Canscora decurrens, herbal plant, antibacterial.

\section{Introduction}

The medicinal value of herbal plants lies in their bioactive principles as plant constituent that produce definite physiological action on the human body (Akinmoladun et al., 2007). Some of them are alkaloids, essential oils, flavonoids, tannins, terpenoid, saponins, phenolic compounds (Edeoga et al., 2005). These natural compounds formed the foundations of modern prescription drugs as we know today (Goh et al., 1995).

There have been a continuous search for especially the native plants or their extracts and many of these herbal remedies proved successful (Gangadevi et al., 2008; Indira lyer et al., 2009; Mungole et al., 2009; Varaprasad Bobbarala et al., 2009).

Canscora decurrens (Dalzell) is an herb belonging to the family Gentianaceae found in tropical and subtropical Africa, Asia, Australia and China. Economically, some species of Gentianaceae are cultivated as ornamental plants and many species yield bitter principles used medicinally and in flavorings. Species of Gentianaceae have been used by people of different countries like India, China etc., as medicine to cure various diseases such as diarrhoea and other stomach ailments. In fact, many plants of Gentianaceae have been known for their antibacterial activity. Swertia corymbosa leaves, traditionally used in Indian medicine as an antidote for poisoning, diarrhoea and as stomach wash in cattle. Hexane, chloroform and methanol extracts show antibacterial activity against a wide range of microorganism, that cause diarrhoea (E. coli, Salmonella, V. cholerae \& Staphylococcus aureus) (Iqbal et al., 2006). Canscora diffusa (Vahl), extracts was found to be effective against both gram-positive and gram-negative bacteria (Mahida \& Mohan, 2006). Canscora decurrens belongs to the same category and therefore it was chosen to study. It is already being utilized in traditional medicine as Shankhapushpi in central India. Present paper is an effort to bring about knowledge of different ethno medicinal uses, chemical constituents and pharmacological activities of in vitro regenerated plant parts to elucidate the actual unexplored medicinal value.

\section{Material and methods}

Canscora decurrens plantlets were in vitro regenerated by standard tissue culture techniques in the plant tissue culture laboratory of SFS Center of biotechnology, Seminary hills, Nagpur. Leaves and roots were separated from the plantlets growing on the tissue culture media and washed repeatedly in distilled water to get rid of the media. The roots and leaves were then oven dried overnight and ground to a fine powder. The powdered form of these plant parts are stored in airtight glass containers, protected from sunlight until required for analysis.

\section{Preliminary phytochemical screening}

Extract preparation: Preliminary phytochemical screening of plant was done according to the standard procedures adopted by the various workers (Amarsingham et al., 1964; Das \& Bhattacharjee, 1970; Gibbs, 1974; Harborne, 1998; Chhabra et al. 1984; Trease \& Evans, 1985; Danial, 1991). Accordingly, the extracts were prepared viz. petroleum ether, chloroform, acetone, ethanol and water. Simple chemical tests were conducted for the chemicals such as, alkaloids, anthocyanins, anthocyanidins, anthraceneglycosides, aminoacids, coumarins, flavanoids, saponins, gums and mucilage, steroids triterpenoids, volatile oils, fatty acids, emodins, carotenoids and tannins.

\section{Antibacterial assay}

The test microorganisms used for the antibacterial activity screening were selected pathogenic bacteria, Staphylococcus aureus, Bacillus subtilis, Rhodococcisp., Escherichia coli, Proteus vulgaris, Pseudomonas sp., and Salmonella $s p$. obtained from the culture collection of Center for Biotechnology, SFS College, Seminary hills, Nagpur, India and Veterinary College, Nagpur, India. All
Research article

CIndian Society for Education and Environment (iSee)
"Medicinal plant" http://www.indjst.org
Mungole et al. Indian J.Sci.Technol. 
bacterial species were maintained on nutrient agar medium for $36 \mathrm{~h}$. Old bacterial cultures were inoculated into nutrient broth and incubated at $37 \pm 2^{\circ} \mathrm{C}$ on rotary shaker at $100 \mathrm{rpm}$. After $36 \mathrm{~h}$ incubation the bacterial suspension were used for further tests. The modified agar well diffusion method (Perez et al., 1990) was used to evaluate the antibacterial activity. Petri dishes and nutrient agar medium was sterilized by autoclaving. To sterilized nutrient agar medium $10 \mathrm{ml}$ of one day old bacterial cultures were added. The medium was stirred well and poured in petri plates and allowed to solidify at room temperature. With the help of a $5 \mathrm{~mm}$ cork borer two wells were punched. To each well $50 \mu$ l extract was poured. The plates were incubated at $37^{\circ} \mathrm{C}$ for $48 \mathrm{~h}$. Finally the plates were observed for clear zone of inhibition and the diameter of zone of inhibition extending laterally around the well was measured in $\mathrm{mm}$ with zone scale of $1 \mathrm{~mm}$ or more considered positive inhibition.

\section{Qualitative and quantitative phytochemical screening}

Quantitative phytochemical screening of flavanoids, phenolics, saponins and alkaloids was done according to the standard procedure adopted by Mallikharjuna et al. (2007). Qualitative analyses of various phytochemicals like alkaloids, flavanoids, phenolics and saponins were done by employing thin layer chromatographic technique as followed by Krishnaiah et al. (2007).

Table 1. Preliminary phytochemical screening

\begin{tabular}{|l|c|c|c|c|c|c|}
\hline \multicolumn{9}{|c|}{ Chemical } & Part & P. ether & Chloroform & Acetone & Ethanol & Water \\
\hline \multirow{2}{*}{ Alkaloids } & Leaf & + & + & + & + & + \\
\cline { 2 - 8 } & Root & + & + & + & + & + \\
\hline \multirow{2}{*}{ Coumarins } & Leaf & + & + & + & + & + \\
\cline { 2 - 8 } & Root & + & + & + & + & + \\
\hline \multirow{2}{*}{ Triterpenoids } & Leaf & - & - & + & - & - \\
\cline { 2 - 8 } & Root & - & - & - & - & - \\
\hline \multirow{2}{*}{ Phenolics } & Leaf & + & + & + & + & - \\
\cline { 2 - 8 } & Root & + & + & + & + & - \\
\hline \multirow{2}{*}{ Flavanoids } & Leaf & + & - & - & - & - \\
\cline { 2 - 8 } & Root & + & - & - & - & - \\
\hline \multirow{2}{*}{ Steroid } & Leaf & + & + & + & - & - \\
\cline { 2 - 8 } & Root & + & + & + & - & - \\
\hline
\end{tabular}

Result and discussions

Phytochemical screening: A general screening was conducted to characterize chemical composition of in vitro regenerated C. decurrens leaf and root samples. It covered mainly nitrogenous compounds, isoprenoids and acetogenins. Screening for nitrogenous compounds was mainly concerned with alkaloids which are reputed to have dramatic physiological activities, mainly on central nervous system. Both the leaf and root samples showed

Table 2. Tests with alcohol \& water extracts

\begin{tabular}{|l|c|c|c|}
\hline Chemical & Part & Ethanol & Water \\
\hline \multirow{2}{*}{ Anthocyanins } & Leaf & - & - \\
\cline { 2 - 4 } & Root & - & - \\
\hline \multirow{2}{*}{ Anthocyanidins } & Leaf & - & - \\
\cline { 2 - 4 } & Root & - & - \\
\hline \multirow{2}{*}{$\begin{array}{l}\text { Anthracene } \\
\text { glycosides }\end{array}$} & Leaf & - & - \\
\cline { 2 - 4 } Tannins & Root & - & - \\
\hline \multirow{2}{*}{$\begin{array}{l}\text { Cardiac } \\
\text { glycosides }\end{array}$} & Leaf & + & + \\
\cline { 2 - 4 } & Root & + & + \\
\cline { 2 - 4 } & Leaf & - & - \\
\hline
\end{tabular}

positive results (Table 1). Phytochemical screening is of paramount importance in identifying new source of therapeutically and industrially valuable compound having medicinal significance, to make the best and judicious use of available natural wealth. A number of medicinal plants have been chemically investigated by several workers (Bhattacharya et al., 1971; Ambashta et al., 1986; Kokate et al., 1998; Ram, 2001).

Acetogenin screening included tannins, flavanoids, coumarins, emodins, anthocyanins, anthocyanidins, anthracene derivatives, phenolic acids and fatty acids. Tannins and coumarin were present in all the extracts of both leaf and root samples (Table $1 \& 2$ ). Tannins decrease the bacterial proliferation by blocking key enzymes at microbial metabolism (Geidam et al., 2007). Tannins play important role such as potent antioxidant (Trease \& Evans, 1985). Herbs that have tannins as their main component are astringent in nature and are used for treating intestinal disorders such as diahorriea and dysentery. Emodins, anthocyanidins, anthocyanins, anthracene glycosides and fatty acids were absent in both the samples (Table $2 \& 3$ ).

Flavanoid was found in the petroleum ether extract of both leaf and root (Table 1). Flavonoids were found to be extractable in all the solvent system. Agrawal and Tiwari (1991) reported flavonoids extracted from Phyllanthus nirurii using solvents- petroleum ether and methanol. However, Phanikumar (2003) could not detect flavonoids in petroleum ether extract from Euphorbia nivulia. Andrei et al. (2000) isolated flavonoids from the roots of Trichosanthes tunicata in hexane. While Zafar and Mujeeb (2002) extracted flavonoids form Tephrosia purpurea in 30\% methanol. Dongarwar (1998) reported these compounds in petroleum ether, methanol and water from the Tephrosia $s p$. Phenolic acid was found to be present in all except water extract (Table 1). In the present study, phenolics were detected in both the parts of the plants. Phenolics have attracted a great attention in relation to their potential for beneficial effects on health. Over the last few years, several experimental studies have revealed biological and pharmacological properties of phenolics compounds, especially their antimicrobial activity (Narayana et al., 1999), antiinflammatory activity (Castillo et al., 1989), antiviral, anti-inflammatory and cytotoxic activity (Chhabra et al., 1984). It is a well documented that most medicinal plants are enriched with phenolic compounds and bioflavonoids that have excellent antioxidant properties (Shirwaikar et al., 2003). Phenolics are active in curing kidney and stomach problems as well as
Research article

CIndian Society for Education and Environment (iSee)
"Medicinal plant" http://www.indjst.org
Mungole et al. Indian J.Sci.Technol. 
helpful as anti-inflammatory in action (Zhu et al., 1997). Choi et al. (1998) found eight types of phenolics form stem bark of Cornus walteri, while, Tiloo (1997) reported the isolation of phenolics from roots of Phyllanthus simplex.

Screening of isoprenoids was confined to steroids, triterpenoids, saponins, cardiac glycosides and carotenoids. Steroids were detected in all extracts except in alcohol and water extracts (Table 1). Steroids have been reported to possess antiinflammatory activities (Chawala et al., 1987) from only stem bark of Phyllanthus flexosus. Saponin which is widely well known to have expectorant activity was observed in water extract. Saponins were also found to be present in both the plant parts (Table 4). Recent studies at Toronto, Department of Nutritional Sciences, Canada, have indicated that, dietary source of saponins offer preferential chemical preventive strategy in lowering the risk of human cancer. Saponins are found in many plants and animals. Rao et al. (1984) and Sharma et al. (1984) carried out an extensive phytochemical analysis of plants for the presence of saponins. Triterpenoids, volatile oils and cardiac glycosides showed negative tests in both the samples whereas carotenoids showed positive result only in leaf sample. The result of qualitative and quantitative phytochemical screening has been given in Table 5 and 7 respectively.
Table 3. Tests with petroleum ether extracts

\begin{tabular}{|c|c|c|}
\hline \multirow{2}{*}{ Chemical } & Part & $\begin{array}{c}\text { Pet. } \\
\text { ether }\end{array}$ \\
\hline \multirow{2}{*}{ Emodins } & Leaf & - \\
\cline { 2 - 3 } & Root & - \\
\hline \multirow{2}{*}{ Carotenoids } & Leaf & + \\
\cline { 2 - 3 } & Root & - \\
\hline \multirow{2}{*}{ Fatty acid } & Leaf & - \\
\cline { 2 - 3 } & Root & - \\
\hline
\end{tabular}
extracts

\begin{tabular}{|c|c|c|}
\hline \multirow{2}{*}{\multicolumn{3}{|c|}{ Chemical }} \\
\hline & & Water \\
\hline \multirow{2}{*}{$\begin{array}{l}\text { Gums \& } \\
\text { Mucilages }\end{array}$} & Leaf & + \\
\hline & Root & + \\
\hline \multirow[t]{2}{*}{ Saponins } & Leaf & + \\
\hline & Root & + \\
\hline \multirow[t]{2}{*}{ Phlobatanin } & Leaf & - \\
\hline & Root & - \\
\hline \multirow{2}{*}{$\begin{array}{l}\text { Chlorogenic } \\
\text { acid }\end{array}$} & Leaf & - \\
\hline & Root & - \\
\hline \multirow{2}{*}{$\begin{array}{l}\text { Cyanogen } \\
\text { glycosides }\end{array}$} & Leaf & - \\
\hline & Root & - \\
\hline
\end{tabular}

Table 5. Quantitative phytochemical analysis

\begin{tabular}{|l|c|c|}
\hline \multirow{2}{*}{ Compound } & \multicolumn{2}{|c|}{$\begin{array}{c}\text { Plant part } \\
\text { (mg/gm of } \\
\text { sample) }\end{array}$} \\
\cline { 2 - 3 } & Leaf & Root \\
\hline Flavonoids & 25 & 20 \\
\hline Phenolics & 5 & 3 \\
\hline Saponins & 135 & 120 \\
\hline Alkaloids & 50 & 62 \\
\hline
\end{tabular}

Table 4. Tests with water Rhodococcisp. Acetone extracts of leaf and root showed the maximum activity against Rhodococci sp. Both the leaf and root extracts showed significant activity against all the test pathogens except E. coli. The ethanol extracts of Canscora decurrens shows absolutely no activity against Salmonella. Maximum activity was observed against Proteus vulgaris. Aqueous extract showed selective antibacterial activity against the test pathogens. Significantly high antibacterial activity was observed against Staphylococcus aureus, Pseudomonas sp. and Rhodococci sp. Whereas absolutely no antibacterial activity was observed against Proteus vulgaris, Salmonella and E. coli.

These observations suggested that the aqueous and organic extracts from the same plants differed in antibacterial effect. Antibacterial effect of the plant extracts on E. coli, Pseudomonas sp. and $S$. aureus suggest that this plant may have potential therapeutic value in the treatment of gastrointestinal disorders, diarrhoea and skin diseases. In addition, the effectiveness of plant was not due to one main active constituent, but the combined action of the chemical compounds (secondary metabolites) involved in it. This finding supports the traditional knowledge in selecting the most active medicinal plants to use in traditional medicine practices in the Antibacterial activity: All the extracts except the petroleum ether showed significant antibacterial activity against the test organisms (Table 6). Petroleum ether extract did not show antibacterial activity against any of the nine pathogenic bacteria. The chloroform extract did not show any activity against $E$. coli. Chloroform extract of roots of Canscora decurrens plantlets showed more activity as

future. Further work is needed to isolate active principle from the plant and to carry out pharmaceutical studies.

Table 6. Screening of in-vitro regenerated Canscora decurrens for antibacterial activity

\begin{tabular}{|c|c|c|c|c|c|c|c|c|c|c|}
\hline \multicolumn{11}{|c|}{ Zone of inhibition in $\mathrm{mm}$ (without $5 \mathrm{~mm}$ well diameter) } \\
\hline \multirow[t]{2}{*}{ Bacteria } & \multicolumn{2}{|c|}{ Pet. ether extract } & \multicolumn{2}{|c|}{$\begin{array}{c}\text { Chloroform } \\
\text { extract }\end{array}$} & \multicolumn{2}{|c|}{$\begin{array}{c}\text { Acetone } \\
\text { extract }\end{array}$} & \multicolumn{2}{|c|}{$\begin{array}{c}\text { Ethanol } \\
\text { extract }\end{array}$} & \multicolumn{2}{|c|}{$\begin{array}{l}\text { Water } \\
\text { extract }\end{array}$} \\
\hline & Leaf & Root & Leaf & Root & Leaf & Root & Leaf & Root & Leaf & Root \\
\hline Salmonella & - & - & 2 & 3 & - & 2 & - & - & - & - \\
\hline Pseudomonas & - & - & 6 & 8 & 4 & 9 & 3 & 4 & - & - \\
\hline Bacillus subtilis & - & - & 6 & 8 & 3 & 11 & 5 & 4 & 9 & 10 \\
\hline Staphylococcus aureus & - & - & 2 & 4 & - & 8 & 2 & 6 & 12 & 23 \\
\hline Proteus vulgaris & - & - & 6 & 6 & 7 & 10 & 11 & 20 & - & - \\
\hline E.coli & - & - & - & - & - & - & 4 & 5 & - & - \\
\hline Rhodococci & - & - & 6 & 7 & 6 & 12 & 4 & 7 & - & 18 \\
\hline Bacillus stearothermophilus & - & - & 6 & 8 & 2 & 11 & 4 & 2 & 16 & 14 \\
\hline
\end{tabular}

Research article

CIndian Society for Education and Environment (iSee)
"Medicinal plant" http://www.indjst.org
Mungole et al. Indian J.Sci.Technol. 
Table 7. Qualitative chemical screening for Thin Layer Chromatography

\begin{tabular}{|c|c|c|c|c|c|}
\hline Chemical & Solvent system & Part & Rf values & $\begin{array}{l}\text { Total } \\
\text { bands }\end{array}$ & $\begin{array}{l}\text { Spray } \\
\text { reagent }\end{array}$ \\
\hline Alkaloids & $\begin{array}{l}\text { Chloroform: Methanol } \\
(15: 1)\end{array}$ & $\begin{array}{l}\text { Leaf } \\
\text { Root }\end{array}$ & ND & ND & $\begin{array}{c}\text { Dragendorf's } \\
\text { reagent }\end{array}$ \\
\hline \multirow{2}{*}{ Flavonoids } & \multirow{2}{*}{$\begin{array}{l}\text { Chloroform: methanol } \\
(19: 1)\end{array}$} & Leaf & 0.838 & 1 & \multirow{2}{*}{$\begin{array}{l}\text { No reagent, } \\
\text { UV light }\end{array}$} \\
\hline & & Root & 0.812 & 1 & \\
\hline \multirow[t]{2}{*}{ Phenolics } & \multirow[t]{2}{*}{$\begin{array}{l}\text { Chloroform: methanol } \\
(27: 0.3)\end{array}$} & Leaf & $\begin{array}{c}0.986,0.93,0.77,0.68,0.527 \\
0.291,0.083,0.04\end{array}$ & 8 & \multirow{2}{*}{$\begin{array}{l}\text { Folin- } \\
\text { Ciocalteau } \\
\text { reagent }\end{array}$} \\
\hline & & Root & $0.986,0.93,0.77,0.506,0.236,0.027$ & 6 & \\
\hline \multirow[b]{2}{*}{ Saponins } & \multirow{2}{*}{$\begin{array}{l}\text { Chloroform: glacial acetic acid: } \\
\text { methanol: water } \\
(64: 34: 12: 8)\end{array}$} & Leaf & $0.53,0.639,0.932$ & 3 & \multirow[b]{2}{*}{ lodine vapors } \\
\hline & & Root & $0.879,0.969$ & 2 & \\
\hline
\end{tabular}

\section{Acknowledgement}

Author is thankful to the Principal of SFS Centre for Biotechnology, St. Francis De Sales College, Seminary Hills, Nagpur for providing the Laboratory facilities and Prof. Mukherjee, Nagpur for his keen interest and valuable guidance.

\section{References}

1. Agrawal T and Tiwari JS (1991) A note on the flavonoid and other constituents of Phyllanthus genus. J. Ind. Chem. Soc. 68, 479-480.

2. Akinmoladun AC, Ibukun EO, Afor E, Obuotor EM and Farombi EO (2007) Phytochemical constituent and antioxidant activity of extract from the leaves of Ocimum gratissimum. Sci. Res. Essay. 2, 163-166.

3. Amarsingham RD, Bisset NG, Millard AH and Woods MC (1964) A Phytochemical survey of Mallaya part III. Alkaloids and saponins. Economic Bot. 3, 270-277.

4. Andrei CC, Ferreira DT, Facciona M, de Moraos LAB, de Carvalho MG and Branz-Filho R (2000) Cprenyalflavoids from roots of Thephrosia tunicate. Phytochem. 55, 799-804.

5. Castillo MH, Perkins E, Campbell JH, Ldoerr R, Hasset JM, Kandaswami C and Middleton E (1989) The effect of the bioflavonoids quercetin on squamous cell carcinoma of head and neck region. Am. J. Surg. 158, 351-355.

6. Chawla AS, Handa SS, Sharma AK and Kaith BS (1987) Plant anti-inflammatory agents. J. Sci. Ind. Res. 46, 214-223.

7. Chhabra SC, Viso FC and Mshiu EN (1984) Phytochemical screening of Tanzanian medicinal plants. J. Ethnopharmacol. 11, 157-179.

8. Choi WH, Park WY, Hwang BY, Oh GJ, Kang SJ, Lee KS and Ro JS (1998) Phenolic compounds from the stem bark of Cornus walteri Wanger. Korean J. Pharmacognosy. 29(3), 217-224.

9. Daniel M (1991) Method in plant chemistry \& economic Botany. Kalyani Publishers, New Delhi, India.
10.Das AK and Bhattacharjee AK (1970) A systematic approach to phytochemical screening. Trop. Sci. XII. pp54-58

11.Dongarwar NM (1998) Ethnobotanical studies on major tribes of Jalgaon, Nashik and part of Thane district of Maharashtra-A preliminary phytochemical observation on some novel medicinal plants. Ph. D. thesis, Nagpur University.

12.Edeoga HO, Okwu DE and Mbaebie BO (2005) Phytochemical Constituents of some Nigerian medicinal plants. Afr. J. Biotechnol. 4(7), 685-688.

13. Gangadevi V, Yogeswari S, Kamalraj S, Rani G and Muthumary $J$ (2008) The antibacterial activity of Acalypha indica L. Indian J.Sci.Technol. 1 (6),1-5. Domain site: http://www.indjst.org.

14.Geidam YA, Ambali AG and Onyeyli PA (2007) Preliminary phytochemical and antibacterial evaluation of crude aqueous extracts of Psidium guajava L. leaf. J. Appl. Sci. 7(4), 511-514.

15. Gibbs RD (1974) Chemotaxonomy of flowering plants I-IV, Motral and London,Mc Gill Quens University Press.

16. Goh SH, Chuah $\mathrm{CH}$, Mok JSL and Soepadmo E (1995) Malaysian medicinal Plants for the treatment of cardiovascular diseases. Selangor Darul Ehsan: Pelanduk Publ. Kaula Lumpur, Malaysia.

17. Harborne JB (eds) (1998) Phytochemical methods: A guide to modern techniques of plant analysis, Chapman \& Hall, London.

18. Indira Iyer R, Jayaraman G and Ramesh A (2009) In vitro responses and production of phytochemicals of potential medicinal value in nutmeg, Myristica fragrans Houtt. Indian J.Sci.Technol. 2 (4), 6570.Domain site: http://www.indjst.org.

19. Iqbal A, Farrukh A and Mohammad O (2006) Modern phytomedicine: Turning medicinal plants into Drugs, Wiley-VCH.

20.Krishnaiah D, Sarbatly R and Bono A (2007) Phytochemical antioxidants for health and medicine- $A$ move towards nature. Biotechnol. Mol. Biol. Rev. 1(4), 97-104.
Research article

CIndian Society for Education and Environment (iSee)
"Medicinal plant" http://www.indjst.org
Mungole et al. Indian J.Sci.Technol. 
21. Mahida $Y$ and Mohan JSS (2006) Screening of Indian plant extracts for antibacterial activity. Pharmaceutical biol. 44, 627-631.

22. Mallikharjuna PB, Rajanna LN, Seetharam YN and Sharanabasappa GK (2007) Phytochemical studies of Strychnos potatorum L.f.- A medicinal plant. Euro. J. Chem. 4, 510-518.

23. Mungole, R. Awati, S. Dey, A. Chaturvedi and $P$. Zanwar (2009) In-vitro callus induction and shoot regeneration in Ipomoea obscura (L.): potent Indian medicinal plant. Indian J.Sci.Technol. 2 (8), 24-26. Domain site:http://www.indjst.org.

24. Narayana KR, Reddy MS, Chaluvadi MR and Krishna DR (1999) Bioflavonoids classification, pharmacology, biochemical effects and therapeutic potential. Ind. J. Pharmacol. 33, 2-16.

25.Perez C, Pauli M and Bazevque P (1990) An antibiotic assay by the agar well diffusion method. Acta Biologiae et Medicine Experimentalis.p: 15.

26. Phanikumar G (2003) A contribution to the phytochemical investigation of some novel plants of Euphorbiaceae having medicinal potential. Ph. D. Thesis, Nagpur University.

27.Rao UP, Brahman M and Saxena HO (1984) Phytochemical surrey of Marurbhanj, Ganjam and Puri district (orrisa) for tannins, saponins, flavonoids. Ind. Drugs. 22(107), 503-507.

28. Sharma SD, Chishti AM and Koul MK (1984) Phytochemical survey of plants from Kashmir-II. Ind. Drugs. 22(4), 187-195.

29. Shirwaikar A, Malini S and Kumari SC (2003) Protective effect of Pongamia pinnata flowers against cisplatin and gentamicin induced nephrotoxicity in rats. Ind. J. Exp. Biol. 1, 58-62.

30.Tiloo V (1997) Ethnobotanical and ethnomedicinal investigation among some tribes of Dhulia district of Maharashtra state. Ph. D. thesis, Nagpur University.

31. Trease GE and Evans WC (1985) Text book of pharmacognosy. English Language Book Society/Bailliere, Tindall Publ., $12^{\text {th }}$ Ed.

32.Varaprasad Bobbarala, Prasanth Kumar Katikala, K. Chandrasekhar Naidu and Somasekhar Penumajji (2009) Antifungal activity of selected plant extracts against phytopathogenic fungi Aspergillus niger F2723. Indian J.Sci.Technol. 2 (4), 87-90. Domain site: http://www.indjst.org.

33.Zafar R and Mujeeb M (2002) Rotenoid and rutin in callus culture of Tephrosia purpurea (L) Pers. Ind. J. Pharma. Sci. 64(3), 217-221.

34.Zhu M, Philliposn D, Greengrass PM, Bowery NE and Cai Y (1997) Plant polyphenols: biologically active compounds or non-selective binder to protein. Phytochem. 44(3), 441-447. 